\title{
Optimasi Konsentrasi Ekstrak dan Bahan Pengikat Polivinil Pirolidon pada Granul Ekstrak Daun Sirih Merah (Piper crocatum Ruiz \& Pav) sebagai Antihiperurisemia
}

\section{(Optimization of Extract Concentration and Polyvinyl Pirolidon Binding Material on Granule Red Betel Leaves Extract (Piper crocatum Ruiz \& Pav) as Antihyperuricemic)}

\author{
DIAN RATIH LAKSMITAWATI*, LILIEK NURHIDAYATI, MOCHAMAD FUTUCHUL \\ ARIFIN , BAGUS BAHTIAR
}

Fakultas Farmasi, Universitas Pancasila

Diterima, 16 Maret 2017, Disetujui 8 Juli 2017

\begin{abstract}
Abstrak: Ekstrak etanol daun sirih merah (Piper crocatum Ruiz \& Pav) memiliki aktivitas antihiperurisemia, agar lebih aplikatif maka perlu dilakukan formulasi dalam bentuk sediaan farmasi. Sediaan yang paling cocok untuk penderita hiperurisemia yang memerlukan lebih banyak minum adalah granul yang dikemas dalam kantung. Dalam proses granulasi, bahan pengikat memegang peranan penting sehingga penelitian ini bertujuan untuk mencari formula granul ekstrak daun sirih merah yang optimum dengan variasi pada dosis ekstrak dan bahan pengikat Polivinil Pirolidon (PVP) dan membuktikan aktivitas granul secara in vivo pada mencit model hiperurisemia. Serbuk daun sirih merah dimaserasi dengan etanol 96\%. Ekstrak kental dikeringkan secara spray drying kemudian diformulasi menjadi granul dengan rancangan faktorial $2^{2}$ yaitu dosis sirih merah (38\% dan 47,51\%) dan PVP $(0,5$ dan $2 \%$ ). Sifat fisika dan kimia granul dievaluasi dan data hasil dianalisis dengan membuat contour plot dan contour plot superimposed untuk menentukan formula optimum. Aktivitas antihiperurisemia granul formula optimum diuji secara in vivo menggunakan mencit model hiperurisemia. Hasil menunjukkan bahwa berdasarkan analisis efek 2 faktor, yaitu konsentrasi PVP dan ekstrak kering, dan interaksi terhadap respon, yaitu organoleptik, kadar lembab granul, sifat alir, distribusi ukuran partikel, waktu melarut dan $\mathrm{pH}$ granul dapat ditetapkan formula optimum granul ekstrak daun sirih merah (Piper crocatum Ruiz \& Pav) yaitu granul dengan bahan pengikat PVP 1\% dan ektrak kering 42,5\%. Dosis granul setara $455 \mathrm{mg} / \mathrm{kg}$ BB ekstrak pada formula ini mempunyai aktivitas menurunkan kadar asam urat sebesar $54,20 \%$ dan signifikan dibandingkan dengan kelompok negatif. Dengan demikian dapat disimpulkan bahwa granul optimum ekstrak etanol daun sirih merah dengan kadar ekstrak $42.5 \%$ dan PVP 1\% terbukti mempunyai aktivitas antihiperurisemia pada mencit yang diinduksi dengan saripati ayam dan kalium oksonat.
\end{abstract}

Kata kunci: Piper crocatum Ruiz \& Pav, sirih merah, antihiperurisemia, formulasi granul.

\begin{abstract}
Ethanolic extract of red betel leaves (Piper crocatum Ruiz \& Pav) has antihyperuricemic activity. In order to be applicable to consume, this extract need to be formulated into pharmaceutical dosage form. Granules which is packed in a tea sac bag was considered to be more practical and appropriate for person suffering hyperuricemic, because they have to drink more water. In the granulation process, the he binder plays an important role so that this study aims to find the optimal red betel leaf granule formula with variation on the extract dose and the polyvinyl pyrolidone (PVP) binder and prove granule activity in vivo in mouse hyperuricemia model. The extract was prepared by maceration the leaves in $96 \%$ ethanol and sprayed dried by hot air. The powder was then formulated to granules form in $2^{2}$ factorial design. The factors were the extract dosages ( $38 \%$ dan $\left.47.51 \%\right)$ dan the amount of PVP (Polyvinyl Pyrrolidone) as a binder ( $0.5 \%$ dan $2 \%)$. The physical and chemical properties of the granules were evaluated, interaction dosage, PVP concentration and each properties was analysed by making the contour plot and superimposed contour plot to get the optimum formula. The in vivo antihyperuricemic activity of the granules was determined in hyperuricemic mice. The result showed that the optimum formula was found in granules that contained $42.5 \%$ extract and $1 \%$ PVP.
\end{abstract}

\footnotetext{
* Penulis korespondensi, Hp. 08161315384

e-mail: dianratih.ffup@gmail.com
} 
At the equivalent dosage of $455 \mathrm{mg}$ extract $/ \mathrm{kg}$, this granules formula had antihyperuricemic activity decreasing $54.2 \%$ plasma uric acid level significantly. Thus it can be concluded that the optimum granules of ethanol extract of red betel leaf with $42.5 \%$ extract content and 1\% PVP proved to have antihiperurisemia activity in mice induced by chicken extract and potassium oxonate

Keywords: Piper crocatum Ruiz \& Pav, red betel, antihyperuricemic, granules.

\section{PENDAHULUAN}

KADAR asam urat darah darah yang meningkat (hiperurisemia) dapat berkembang menjadi penyakit gout yang sangat mengganggu. Gout adalah penyakit yang ditandai dengan peradangan sendi sehingga mengganggu aktivitas kerja. Dari penelitian sebelumnya ekstrak etanol daun sirih merah diketahui memiliki aktivitas antihiperurisemia yang cukup berpotensi. Secara in vitro melalui metode penghambatan enzim xantin oksidase diketahui bahwa ekstrak sirih merah mempunyai potensi penghambat terbesar dibandingkan dengan ekstrak tanaman lain yang diteliti secara bersamaan yaitu ekstrak daun sirsak, binahong dan gandarusa ${ }^{(1)}$. Uji in vivo antihiperurisemia menggunakan mencit yang diinduksi dengan kalium oksonat dan saripati ayam menunjukkan bahwa ekstrak daun sirih pada dosis 400 $\mathrm{mg} / \mathrm{kg}$ BB dan $500 \mathrm{mg} / \mathrm{kg}$ BB dapat menurunkan kadar asam urat sebesar $54,04 \%$ dan $55,90 \%{ }^{(2)}$.

Pemanfaatan daun sirih merah secara tradisional untuk pengobatan biasanya dalam bentuk rebusan daun segar. Cara penggunaan tersebut dipandang tidak praktis dan rasanya tidak disukai. Selain itu dosis yang digunakan cukup besar yaitu 38\% dan 47\% sehingga jika diformulasi ke dalam bentuk sediaan kapsul atau tablet akan mengakibatkan pasien harus mengonsumsi 2 atau lebih tablet untuk sekali minum. Hal ini akan menimbulkan permasalahan ketidakpatuhan pada pasien sehingga tujuan pengobatan menjadi tidak efektif. Untuk mengatasi masalah dosis maka daun sirih perlu diekstraksi. Ekstrak kering bersifat voluminous sehingga perlu dilakukan granulasi untuk meningkatkan bobot jenisnya.

Granulasi adalah proses pembentukan partikelpartikel besar dengan mekanisme pengikatan tertentu. Tujuannya antara lain untuk meningkatkan bobot jenis, meningkatkan sifat alir, dan mengurangi terbentuknya debu. Dalam proses granulasi, bahan pengikat memegang peranan penting yaitu sebagai bahan yang mempunyai sifat kohesif sehingga mampu mengaglomerasi partikel serbuk kering membentuk granul setelah pengeringan. Salah satu bahan pengikat yang sering digunakan adalah Poli Vinil Pirolidon
$(\mathrm{PVP})^{(3)}$.

Agar ekstrak daun sirih merah lebih mudah dikonsumsi maka perlu dilakukan formulasi menjadi bentuk sediaan farmasi berbentuk granul yang dikemas dalam kantung seperti teh celup. Granul dilarutkan dengan cara mencelupkan berulang kali dalam air minum hangat. Melarutkan granul menggunakan air minum dimaksudkan agar penderita hiperurisemia dapat memperbanyak konsumsi air minum untuk meningkatkan kelarutan kristal asam urat.

Konsentrasi bahan pengikat sangat menentukan sifat alir, sudut diam, fitness dan kompaktibilitas granul. Penelitian ini bertujuan untuk mencari formula granul ekstrak sirih merah yang optimum dan stabil secara kimia, fisika serta aktivitas farmakologi antihiperurisemia selama uji stabilitas. Disain yang digunakan dalam penelitian adalah rancangan faktorial $2^{2}$ untuk menjelaskan efek dari 2 faktor meliputi konsentrasi ekstrak kering daun sirih merah (38\% dan $47,51 \%)$ dan konsentrasi bahan pengikat PVP $(0,5 \%$ dan $2 \%$ ) sehingga akan diperoleh 4 formula.

\section{BAHAN DAN METODE}

BAHAN. Daun sirih merah yang diperoleh dari area Bogor Jawa Barat dan dideterminasi oleh LIPI, Cibinong sebagai Piper crocatum Ruiz\& Pav. Bahan lain yang dipergunakan adalah etanol 96\%, maltodekstrin, PVP, eritrosin, aerosil, natrium benzoat, aspartame, laktosa, kalium oksonat (Sigma 1561245G), saripati ayam (Brand's), mencit jantan galur DDY diperoleh dari Laboratorium Non Ruminansia dan Satwa Harapan dan kit asam urat (Biolabo), Alopurinol (bahan baku dari Indofarma).

Alat. Kandang mencit, sonde oral, sentrifugasi (PLC-03 serial No. 502406), pipa kapiler $5 \mu \mathrm{L}$, Microlab 300, blender, alat maserasi kinetik, kertas saring, vakum rotavapor, spray dryer, rotary vacuum evaporator, oven (Memmert), climatic chamber (Memmert), homogenizer (Hsiangtai), lemari pendingin, timbangan analitik (AND tipe GR 200), spray dryer (Buchi 190), ayakan mesh 14 dan 16, Alat uji sifat alir (Autonics LE3S), stopwatch, Pengayak 
bertingkat (BBS Product BCL-601), alat uji ukuran partikel (Tsutsui), alat - alat gelas laboratorium.

Ekstraksi dan Formulasi. Daun sirih merah dibuat simplisia kering selanjutnya diserbukan kemudian dimaserasi sebanyak 5 kali dengan pelarut etanol 96\% dengan pengadukan kontinyu masing-masing selama 3 jam. Filtrat maserat yang diuapkan dengan rotary evaporator sampai menjadi kental. Sejumlah ekstrak kental daun sirih merah diencerkan dalam air dicampurkan dengan larutan maltodekstrin, dikeringkan dengan pengeringan semprot (spray drying) pada suhu inlet $190{ }^{\circ} \mathrm{C}$ dan oulet $80{ }^{\circ} \mathrm{C}$. Formula dibuat sebanyak 4 macam dengan menggunakan rancangan faktorial $2^{2}$ dengan dua faktor variasi yaitu konsentrasi ekstrak daun sirih merah dan konsentrasi bahan pengikat PVP. Formula dapat dilihat pada Tabel 1.

\begin{tabular}{llcccc}
\multicolumn{5}{c}{ Tabel 1. Variasi Formula Granul. } \\
\hline \multirow{2}{*}{ No } & \multirow{2}{*}{ Bahan } & \multicolumn{4}{c}{ Jumlah (\%) } \\
\cline { 3 - 6 } & & Formula 1 & Formula 2 & Formula 3 & Formula 4 \\
\hline 1 & Ekstrak kering & 38 & 47,51 & 38 & 47,51 \\
2 & PVP & 0,5 & 0,5 & 2 & 2 \\
3 & Eritrosin & 0.05 & 0,05 & 0.05 & 0,05 \\
4 & Aspartam & 2 & 2 & 2 & 2 \\
5 & Na benzoat & 0.1 & 0,1 & 0,1 & 0,1 \\
6 & Aerosil & 0,5 & 0,5 & 0.5 & 0,5 \\
7 & Laktosa (ad) & 100 & 100 & 100 & 100 \\
\hline
\end{tabular}

Ekstrak kering hasil spray $d r y$ digerus dengan laktosa dalam mortir kemudian dicampur dengan aspartam, eritrosin dan PVP, lalu diaduk sampai homogen. Campuran serbuk ditambahkan etanol 95\% sedikit demi sedikit sambil diaduk hingga didapatkan massa yang kompak dan massa yang diperoleh diayak dengan pengayak mesh nomor 12 . Hasil ayakan dikeringkan dalam oven suhu $50-60{ }^{\circ} \mathrm{C}$ selama 60 menit. Granul kering diayak kembali dengan pengayak mesh nomor 14 dan ditambahkan aerosil sebagai fase luar dan dievaluasi meliputi organoleptik, kadar lembab, sifat alir, distribusi ukuran partikel, $\mathrm{pH}$, dan waktu melarut.

Evaluasi Granul. Granul dari 4 formula dievaluasi sifat fisik dan kimia meliputi : uji organoleptik, kadar lembab ${ }^{(4)}$, sifat alir ${ }^{(5)}$, distribusi ukuran partikel, $\mathrm{pH}$, dan waktu melarut ${ }^{(6)}$. Masing-masing respon dibuat contour plot dan contour plot super imposed untuk mendapatkan formula optimum. Selanjutnya formula optimum diuji aktivitas antiinflamasi dan stabilitasnya selama 4 minggu pada suhu $40{ }^{\circ} \mathrm{C}$ dan kelembaban relative $75 \%$. Sifat fisika dan kimia sediaan granul optimum dievaluasi pada minggu ke- 0,2 dan 4 , sedangkan uji aktivitas dilakukan pada minggu ke-0 dan 4.

Uji In Vivo Aktivitas Antihiperurisemia ${ }^{(7)}$. Uji ini mengikuti post test control group design. Selama percobaan mencit jantan galur DDY dengan berat antara 20-30 g dipelihara guna menyesuaikan kondisi lingkungan percobaan dengan pemberian pakan standar dan minum ad libitum selama 7 hari. Setelah aklimatisasi selesai dilakukan mencit percobaan dibagi acak dalam 5 kelompok yaitu kelompok 1 normal (mencit sehat tanpa perlakuan), kelompok 2 (kelompok negative: mencit diinduksi hiperurisemia tanpa pemberian ekstrak/obat), kelompok 3 (kelompok perlakuan granul: mencit diinduksi hiperurisemia serta diobati dengan granul), kelompok 4 (kelompok granul placebo: mencit diinduksi hiperurisemia serta diobati dengan granul placebo (tanpa ekstrak sirih merah)) dan kelompok 5 (kelompok alopurinol : mencit diinduksi hiperurisemia serta diobati dengan granul). Prosedur pemberian perlakuan sebagai berikut : selama 3 hari mencit diberi kalium oksonat intra peritoneal dosis $250 \mathrm{mg} / \mathrm{kg}$ BB. Satu jam setelah pemberian kalium oksonat mencit diberikan saripati ayam (Brand's essence of chicken) sebanyak $20 \mathrm{~mL} /$ $\mathrm{kg}$ BB secara oral. Selang 1 jam kemudian untuk mencit diberi granul/granul plasebo/alopurinol secara oral sesuai dengan kelompoknya. Dosis granul yang digunakan adalah setara dengan ekstrak $455 \mathrm{mg} / \mathrm{kg}$ BB, sedangkan untuk alopurinol sebanyak $300 \mathrm{mg} /$ $\mathrm{kg} \mathrm{BB}$ ). Pada hari kedua malam, mencit dipuasakan selama 12 jam dan keesokan harinya yaitu hari ketiga, dilakukan pengambilan darah dari vena orbitalis mata, 1 jam setelah setelah pemberian perlakuan. Darah disentrifus untuk diambil plasmanya. Plasma darah di reaksikan dengan pereaksi asam urat Biolabo dan diukur menggunakan instrumentasi Microlab 300 pada $\lambda 546 \mathrm{~nm}$.

\section{HASIL DAN PEMBAHASAN}

Organoleptik, Kadar Lembab Granul, Sifat Alir Granul. Pada Tabel 2. terlihat bahwa secara organoleptic formula I dan III granul yang dihasilkan berkurang rasa pahitnya dibandingkan dengan formula II dan IV. Perbedaan rasa granul dipengaruhi oleh dosis ekstrak yang digunakan. Semakin besar dosis yang digunakan maka semakin besar pula kandungan senyawa golongan tanin yang terkandung di dalamnya sehingga akan meningkatkan rasa pahit granul.

Hasil evaluasi kadar lembab granul menunjukkan bahwa keempat formula granul memenuhi syarat kadar lembab dengan rentang antara 2,42\% hingga 
Tabel 2. Hasil Evaluasi Organoleptik, Kadar Lembab Granul, Sifat Alir Granul.

\begin{tabular}{|c|c|c|c|c|c|c|}
\hline \multirow{3}{*}{ Formula } & \multicolumn{3}{|c|}{ Organoleptiti } & \multirow{3}{*}{$\begin{array}{c}\text { Radar } \\
\text { lembab }{ }^{(f)} \\
(\%)\end{array}$} & \multirow{3}{*}{$\begin{array}{c}\text { Keceppatan } \\
\text { Alilir) } \\
\text { (g detik) }\end{array}$} & \multirow{3}{*}{$\begin{array}{c}\text { Sudut Diam a } \\
\text { (9) }\end{array}$} \\
\hline & Wama & Bau & Rasa & & & \\
\hline & & & & & & \\
\hline I & Merah & Khas aromatili & Agakpahit & $2.42=0.12^{*}$ & $4,08=0.29^{\circ}$ & $25.50=0.60^{10}$ \\
\hline II & Merah & Khas arometil & Pahit & $3.15=0.06^{*}$ & $4.84 \pm 0,11^{*}$ & $20.19=3.26^{* *}$ \\
\hline III & Merah & Khas arometili & Agak pahit & $2.75=0.08^{7}$ & $5,41=0,57^{*}$ & $12.02=0,53^{* \text { * }}$ \\
\hline IN & Merah & Khas arometik & Palit & $3.96=0.13^{*}$ & $5,17=0,60^{*}$ & $19.95=1.28 \% *$ \\
\hline
\end{tabular}

$3,96 \%$. Persyaratan kadar lembab granul yaitu $2-4 \%{ }^{(8)}$. Kadar lembab pada granul yang tinggi dapat memicu pertumbuhan mikroorganisme yang tidak diinginkan sehingga sediaan dengan bahan alam tidak dapat bertahan lama dan akan mengurangi stabilitas sediaan dalam penyimpanan.

Hasil evaluasi kecepatan alir granul keseluruhan formula pada Tabel 2. diperoleh rentang kecepatan alir antara 4,08 g/detik - 5,41 g/detik yang menunjukkan bahwa semua formula granul memenuhi syarat kecepatan alir. Selain kecepatan alir, sifat alir granul juga ditentukan oleh sudut diam. Hasil evaluasi sudut diam granul diperoleh rentang antara $12,02^{\circ}$ - 25,50 sehingga dapat disimpulkan bahwa semua formula granul memenuhi syarat sudut diam. Uji sifat alir granul penting dilakukan untuk mengetahui kemampuan mengalir granul. Dengan kemampuan mengalir yang baik akan memudahkan granul mengalir pada mesin pengemasan sehingga menjamin ketepatan dosis yang tinggi.

Distribusi Ukuran Partikel, Waktu Melarut dan pH Granul. Tabel 3 memperlihatkan diameter rata-rata partikel granul, waktu melarut dan $\mathrm{pH}$ granul formula I-IV. Evaluasi distribusi ukuran partikel bertujuan untuk mengetahui diameter rata-rata partikel granul dan penyebaran ukuran partikelnya. Diameter rata-rata partikel granul formula I-IV dapat dilihat pada tabel 3 , hasil yang diperoleh yaitu diameternya berkisar antara 369,01 $\mu \mathrm{m}-425,34 \mu \mathrm{m}$. Distribusi

Tabel 3. Diameter ukuran partikel, waktu melarut dan pH granul.

\begin{tabular}{cccc}
\hline Formula & Diameter rata-rata (um) & Waktu melarut ${ }^{(4)}$ & $\mathrm{pH}$ \\
\hline I & 425,34 & 3 menit 50 detik $^{*}$ & $5,49=0,0416^{*}$ \\
II & 369,01 & 2 menit 09 detik* & $4,94=0,0058^{*}$ \\
III & 371,94 & 7 menit 08 detik* & $5,13=0,0153^{*}$ \\
IV & 378,27 & 9 menit 17 detik* & $4,78 \pm 0,02^{*}$ \\
\hline
\end{tabular}

Keterangan : * memenuhi syarat pustaka.

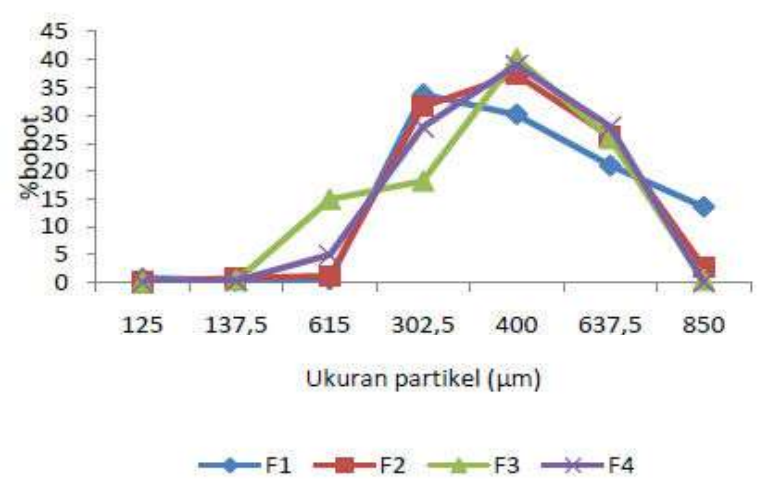

Gambar 1. Kurva distribusi ukuran partikel granul.

ukuran partikel dapat dilihat pada Gambar 1. Grafik distribusi yang baik adalah grafik yang menunjukkan hasil presentase penyebaran granul tertinggal di nomor mesh kecil dan nomor mesh besar harus seimbang dan presentase penyebaran granul yang tertinggal di nomor mesh tengah harus besar. Dengan demikian dapat disimpulkan bahwa ukuran partikel granul ekstrak kering daun sirih merah terdistribusi dengan baik.

Selain mengetahui penyebaran ukuran partikel, kurva distribusi ukuran partikel juga dapat digunakan untuk melihat ukuran partikel yang paling dominan. Dari Gambar 1. dapat dilihat bahwa ukuran partikel yang paling dominan dari keseluruhan formula yaitu $400 \mu \mathrm{m}$. Menurut literatur, granul dengan ukuran partikel $>250 \mu \mathrm{m}$ memiliki sifat mengalir bebas ${ }^{(5)}$. Hal ini menunjukkan bahwa semua formula granul mempunyai sifat alir yang baik sehingga akan mengalir bebas ke dalam kemasan dan menjamin keseragaman dosis sediaan.

Hasil evaluasi waktu melarut granul formula I dan II pada Tabel 3. memenuhi persyaratan yaitu 3 menit 50 detik dan 2 menit 09 detik. Sedangkan waktu melarut formula III dan IV tidak memenuhi persyaratan karena lebih dari 5 menit. Perbedaan waktu melarut granul dipengaruhi oleh konsentrasi bahan pengikat PVP yang digunakan. Formula I dan II menggunakan PVP konsentrasi $0,5 \%$ dan formua III dan IV menggunakan PVP konsentrasi 2\%. Waktu melarut granul penting untuk diketahui karena sediaan yang dihasilkan diharapkan dapat melarut sempurna dalam waktu singkat sehingga dapat segera digunakan setelah dilarutkan dan memberikan efek yang optimal.

Berdasarkan hasil uji $\mathrm{pH}$ granul dapat diamati bahwa keempat formula memiliki $\mathrm{pH}$ asam. Hal ini sesuai dengan literatur bahwa $\mathrm{pH}$ sirih merah tergolong asam karena dipengaruhi oleh kandungan flavonoid antosianin dalam ekstrak yang juga bersifat asam. Tujuan dilakukan uji $\mathrm{pH}$ yaitu untuk mengetahui $\mathrm{pH}$ granul ekstrak kering daun sirih merah sebagai parameter kestabilan kimia sediaan. 
Analisis Efek Faktor dan Interaksi Terhadap Respon. Efek faktor (konsentrasi PVP dan dosis ekstrak) dan interaksinya dengan organoleptik, kadar lembab granul, sifat alir, distribusi ukuran partikel, waktu melarut dan $\mathrm{pH}$ granul dianalisis secara sehingga diperoleh contour plot seperti pada Gambar 2. (A,B,C,D dan E). Dari hasil analisis tersebut diperoleh hasil bahwa dosis ekstrak kering sirih merah dan konsentrasi PVP memiliki efek dominan dalam meningkatkan kadar lembab granul. Peningkatan konsentrasi PVP berpengaruh secara signifikan dalam meningkatkan kecepatan alir granul karena nilai pvalue $<0,05$ dan efek peningkatannya sebesar 0,7155 . Berbeda dengan kecepatan alir, peningkatan konsentrasi PVP akan menurunkan sudut diam secara signifikan. PVP merupakan bahan pengikat yang dapat menghasilkan granul dengan sifat alir yang baik. PVP mampu meningkatkan gaya tarik-menarik antar partikel sehingga dapat membentuk masa padatan yang kompak. Masa kompak yang terbentuk ketika diayak akan terbentuk partikel granul yang spheris. Bentuk partikel granul yang spheris dapat mengurangi gesekan antar partikel, sehingga dapat meningkatkan laju alir dan menurunkan sudut diam. Sudut diam berbanding terbalik dengan laju alir. Semakin kecil sudut diam, maka semakin baik laju alir granul yang dihasilkan $^{(5)}$.

Peningkatan dosis ekstrak, konsentrasi PVP, dan interaksi keduanya berpengaruh secara signifikan dalam meningkatkan waktu melarut granul dengan nilai pvalue $<0,05$, namun efek peningkatan dominan dipengaruhi oleh konsentrasi PVP. PVP yang digunakan akan memperkuat ikatan antar partikel granul sehingga granul yang dihasilkan cenderung lebih kompak akibatnya waktu melarut granul menjadi lebih lama. Oleh karena itu sebaiknya digunakan PVP dalam konsentrasi yang rendah $(<2 \%)$ agar tidak meningkatkan waktu melarut granul. Dosis ekstrak kering dan konsentrasi PVP memiliki efek signifikan dalam menurunkan $\mathrm{pH}$ sediaan, namun efek dominan dipengaruhi oleh dosis ekstrak kering.

\begin{tabular}{|c|c|c|}
\hline Respon & $\begin{array}{c}\text { Batas } \\
\text { minimum }\end{array}$ & $\begin{array}{c}\text { Batas } \\
\text { maksimum }\end{array}$ \\
\hline Sifat alir ${ }^{(5)}$ & 4 & 10 \\
\hline Sudut diam ${ }^{(5)}$ & 20 & 30 \\
\hline Kadar lembab ${ }^{(4)}$ & 2 & 4 \\
\hline $\mathrm{pH}$ & 4.54 & 5.52 \\
\hline Waktu melarut ${ }^{(6)}$ & 1 & 5 \\
\hline
\end{tabular}
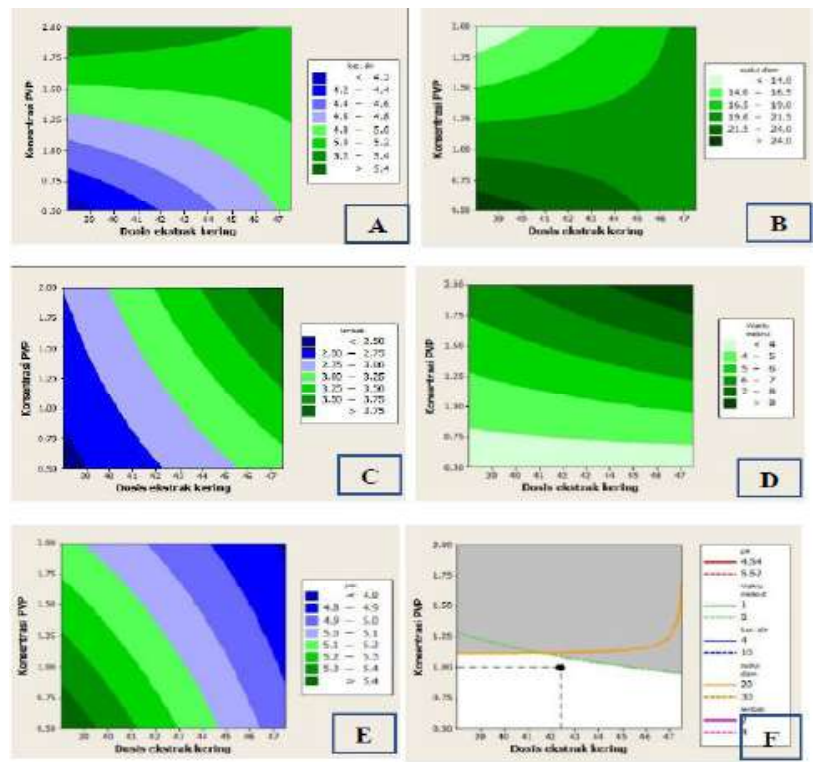

Gambar 2. Countor Plot Hasil Analisis Efek-Respon.

Keterangan : Countour plot konsentrasi PVP, dosis ekstrak kering vs kecepatan alir (A), sudut diam (B), kadar lembab (C), waktu melarut (D), $\mathrm{pH}$ (E). Countour plot super imposed antara $\mathrm{pH}$, waktu melarut, kecepatan alir, sudut diam dan kadar lembab, tanda bulatan hitam menandakan komposisi formula optimum yang dipilih (F).

Setelah diperoleh contour plot pada Gambar 2., kemudian ditentukan batas minimum dan maksimum dari masing-masing respon berdasarkan literatur seperti terlihat pada Tabel 4. (Kriteria Batas Respon). Untuk menentukan formula optimum, masing-masing contour plot ditumpangtindihkan sehingga diperoleh grafik contour plot superimposed pada Gambar 2 (F). Dari Gambar 2 (F). diperoleh irisan putih yang merupakan daerah komposisi formula optimum kemudian ditentukan satu titik yang menghubungkan dosis ekstrak kering dan juga konsentrasi PVP untuk digunakan dalam formulasi formula optimum. Formula optimum yang digunakan pada penelitian yaitu formula dengan konsentrasi ekstrak kering daun sirih merah 42,5\% dan konsentrasi PVP $1 \%$. (formula II).

Aktivitas Antihiperurisemia Granul Formula II. Hasil pengukuran dapat dilihat pada Tabel 5.

\begin{tabular}{|c|c|c|}
\hline Kelompok & $\begin{array}{l}\text { Kadar asam urat } \\
(\mathrm{mg} d \mathrm{dL})=\mathrm{SD}\end{array}$ & $\begin{array}{l}\text { Persentase penurunan } \\
\text { kadar asam urat }(\%)\end{array}$ \\
\hline Kontrol Normal & $0,944 \pm 0.09^{2}$ & $\mathrm{TD}^{* / 4}$ \\
\hline Kontrol Hiperurisemia & $1,415 \pm 0,13^{b}$ & $0 \%$ \\
\hline Allopurinol $300 \mathrm{mg} \mathrm{kg} \mathrm{BB}$ & $0.236 \pm 0.09^{c}$ & $83.32 \%$ \\
\hline Granul Plasebo & $1,01 \pm 0,13^{2 \mathrm{~d}}$ & $28.62 \%$ \\
\hline $\begin{array}{c}\text { Granul formula II (optimum) } \\
\text { (dosis } 455 \mathrm{mg} \mathrm{kg} \text { BB ) }\end{array}$ & $0,648 \pm 0.24^{\mathrm{e}}$ & $54.20 \%$ \\
\hline
\end{tabular}


Keterangan : * dihitung terhadap kelompok kontrol hiperurisemia, ** :TD tidak dihitung, huruf a, b, c, d, e: bila antar kelompok mempunyai tanda satu huruf yang sama menunjukkan tidak ada hubungan bermakna $(\mathrm{P}>0.05)$.

Berdasarkan Tabel 4. kadar asam urat kelompok negatif (kelompok yang dibuat hiperurisemia tanpa diobati) mencapai nilai tertinggi yaitu $1,415 \pm 0,13$ $\mathrm{mg} / \mathrm{dL}$. Kelompok mencit yang diberi perlakuan granul dosis 455 gram $/ \mathrm{kg}$ memperlihatkan efek antihiperurisemia dilihat dari tercapainya kadar asam urat lebih rendah sebesar 0,648 $\pm 0,24 \mathrm{mg} / \mathrm{dL}$. Kelompok mencit yang diobati dengan alopurinol mencapai kadar asam urat sebesar 0,236 $\pm 0,09 \mathrm{mg} /$ dL. Kelompok yang diberi granul plasebo mencapai kadar asam urat sebesar $1,01 \pm 0,13 \mathrm{mg} / \mathrm{dL}$.

Kadar asam urat pada mencit normal di penelitian ini adalah 0,944 $\pm 0,09 \mathrm{mg} / \mathrm{dL}$. Kadar asam urat meningkat signifikan sebanyak 49,8\% menjadi $1,415 \pm 0,13 \mathrm{mg} / \mathrm{dL}$ pada kelompok yang diinduksi menggunakan saripati ayam $20 \mathrm{~mL} / \mathrm{kg}$ BB dan kalium oksonat intraperitoneal dosis $250 \mathrm{mg} / \mathrm{kg} \mathrm{BB}$ selama 3 hari, $(p<0.05)$. Saripati ayam adalah cairan yang berisi ekstrak ayam dengan kandungan protein dan purin yang tinggi. Senyawa nukleotida purin akan dikatabolisme membentuk asam urat dalam plasma. Kalium oksonat adalah senyawa kimia yang berperan sebagai inhibitor enzim urat oksidase, yaitu enzim dalam tubuh mencit yang bertanggung jawab mengubah asam urat menjadi alantoin. Penambahan kalium oksonat ini merupakan strategi untuk membuat mencit model hiperurisemia. Mencit mempunyai enzim urat oksidase, yang tidak dimiliki oleh manusia. Aktivitas alamiah urat oksidase dapat melemahkan metode ini, sebab asam urat yang akan dideteksi dapat diubah menjadi senyawa lain. Untuk mencegah kehilangan asam urat karena konversi menjadi alantoin maka harus ditambahkan penghambat urat oksidase.

Pemberian granul optimum yang dibuat dalam penelitian ini pada dosis 455 gram $/ \mathrm{kg}$ mampu menurunkan kadar asam urat sebesar $54,20 \%$ dan berbeda signifikan dengan granul plasebo $(\mathrm{p}<0.05)$. Besarnya aktivitas antihiperurisemia formula granul ini masih lebih kecil bila dibandingkan dengan obat alopurinol. Kelompok mencit yang diberi alopurinol mencapai kadar asam urat sebesar 0,236 $\pm 0,09 \mathrm{mg} /$ dL dengan persentase penurunan sebanyak $83,32 \%$ dari kelompok negative yaitu kelompok yang tidak diobati. Namun kadar asam urat yang dicapai kelompok alopurinol berada dibawah kadar asam urat mencit kelompok normal dan berbeda signifikan. Kadar asam urat dibawah normal dapat menyebabkan berkurangnya kapasitas antioksidan endogen, sebab asam urat termasuk senyawa antioksidan endogen yang dapat menangkal beban oksidatif radikal bebas. Apabila kondisi kadar asam urat terlalu rendah dan berlangsung lama maka dikuatirkan terjadi penurunan antioksidan tubuh.

Ekstrak daun sirih merah diketahui mengandung senyawa diantaranya adalah flavonoid, saponin, dan $\operatorname{tannin}^{(2)}$. Senyawa flavonoid dan turunannya seperti krisin, apigenin, kuersetin, luteolin, galangin, dan kaemferol yang memiliki aktivitas penghambatan xantin oksidase ${ }^{(9)}$. Flavonoid dengan struktur benzopiran dilaporkan mempunyai mekanisme inhibisi kompetitif terhadap enzim xantin oksidase dalam menghambat katalisis xantin menjadi asam urat $^{(5)}$.

Dari hasil analisis efek faktor dan interaksi terhadap respon pada penelitian ini, PVP meningkatkan kadar lembab, untuk mengantisipasinya dapat digunakan kemasan sekunder berbahan alumunium dengan tambahan butiran pengering silika gel dan disimpan dalam wadah tertutup di tempat sejuk dan kering.

\section{SIMPULAN}

Berdasarkan analisis efek 2 faktor, yaitu konsentrasi PVP dan ekstrak kering, dan interaksi terhadap respon, yaitu organoleptik, kadar lembab granul, sifat alir, distribusi ukuran partikel, waktu melarut dan $\mathrm{pH}$ granul dapat ditetapkan formula optimum granul ekstrak daun sirih merah (Piper crocatum Ruiz \& $P a v)$ yaitu granul dengan bahan pengikat PVP 1\% dan ektrak kering 42,5\%. Dosis granul sebesar $455 \mathrm{mg} / \mathrm{kg}$ berat badan mencit memberikan aktivitas menurunkan kadar asam urat darah mencit hiperurisemia sampai kadar normal kembali. Besarnya penurunan kadar asam urat adalah 54,20\% dan signifikan dibandingkan dengan kelompok negative dengan pemberian 1 kali sehari selama 3 hari dan tercapai kadar asam urat normal. Untuk mengantisipasi lembab selama penyimpanan dapat digunakan kemasan sekunder berbahan alumunium dengan tambahan butiran pengering silika gel dan disimpan dalam wadah tertutup di tempat sejuk dan kering.

\section{UCAPAN TERIMA KASIH}

Ucapan terima kasih disampaikan kepada Direktorat Riset dan Pengabdian Masyarakat Kemenristek Dikti atas pendanaan Hibah Bersaing tahun 2016 (tahun ketiga) dengan judul proposal "Eksplorasi Inhibitor Xantin Oksidase Dari Beberapa Tanaman dan 
Pengembangannya Sebagai Antihiperurisemia" (tahun ketiga) Surat Kemenristek Dikti No. 0299/E3/2016, tanggal 27 Januari 2016 melalui Kontrak Penugasan no. 2563/LPPM/UP/VII/2016.

\section{DAFTAR PUSTAKA}

1. Laksmitawati DR, Muslihah A, Wulandari, Rinawati, Santi, Activisionis D. Skrining aktivitas penghambatan enzim xantin oksidase ekstrak 4 tanaman terpilih secara in vitro . Makalah Seminar Nasional Himpunan Kimia Bahan Alam Indonesia (HKBAI) UPI Bandung 21-22 Oktober 2014.

2. Laksmitawati DR, Rahmawaty H, Nurhidayati L. Potensi antihiperurisemia dari senyawa hasil fraksinasi fase etil asetat ekstrak etanol $96 \%$ daun sirih merah Prosiding Seminar Nasional Ilmu Farmasi Universitas Jendral Ahmad Yani (Unjani) ISBN 978.602-73060-1-1, 2015 hal 23-7.

3. Folttmann H., Quadir A., Polyvinylpyrrolidone (PVP)-One of the Most Widely Used Excipients In Pharmaceuticals: An Overview, Drug delivery Technology, June 2008, Vol 8 No 6.

4. Lachman L, Lieberman HA, Kanig JL. Teori dan praktek farmasi industri Ed III Vol. 1. diterjemahkan oleh Siti Suyatmi. Jakarta: UI Press; 2007. h.227-57

5. Aulton, ME. Pharmaceutic the science of dosage form design. 2nd ed. Churchill Livingstone. 2000.

6. Badan Pengawas Obat dan Makanan Republik
Indonesia. Peraturan Kepala Badan Pengawas Obat dan Makanan Republik Indonesia Nomor 12 tahun 2014 Tentang Persyaratan Mutu Obat Tradisional. Kepala Badan Pengawas Obat dan Makanan Republik Indonesia; 2014.

7. Laksmitawati DR, Nurhidayati L, Novita N. Establishment Of Hyperuricemia Mouse Model With Oxonic Acid Potassium Salt And Essence Of Chicken. RJPBCS 8(1S) January - February, 2017(Suppl.), p.64-9.

8. Laksmitawati DR, Nurhidayati L, Arifin MF, Eksplorasi Inhibitor Xantin Oksidase Dari Beberapa Tanaman dan Pengembangannya Sebagai Antihiperurisemia. Laporan Akhir Penelitian Hibah Bersaing Kemenristek Dikti (tahun ketiga), Oktober 2016.

9. Cos P, Ying L, Calomme M, Hu JP, Cimanga K, Poel BV, et al. Structure-activity relationship and classification of flavonoid as inhibitors of xanthine oxsidase and superoxidase scavengers. J Nat Prod. 1998;61:71-6. 